\title{
"He Has Lifted the Iron Curtain": Reflections on Ján Cikker's Literaturopern and Their Reception ${ }^{1}$
}

\author{
Vladimír ZvarA \\ Filozofická fakulta, Univerzita Komenského \\ Gondova 2, P.O. Box 32, 81499 Bratislava 1, Slovakia \\ Email: vladimir.zvara@uniba.sk
}

(Received: March 2018; accepted: June 2018)

\begin{abstract}
During the 1960s, the operatic works of Slovak composer Ján Cikker were among the most often performed contemporary operas in Europe, especially in the two German states. The reasons of this success are as interesting as the reasons of the decline that occurred during the 1970s. In both cases, the intensity of the publisher Bärenreiter's support and marketing played an important role, as did the change of the audience's taste which brought a general decrease in the popularity of the post-war Literaturoper in the tradition of Richard Strauss, the music of which was moderately modern and did not fulfill (as it was not meant to fulfill) the requirements of New Music. The reception of Cikker's work, its aesthetic background, and its musical and dramatic solutions are exemplified within his chef d'oeuvre, the opera Vzkriesenie (Resurrection, 1962), based on Tolstoy's novel, which is highly consistent in its dramaturgy thanks to Fritz Oeser, the libretto's silent co-author.
\end{abstract}

Keywords: Ján Cikker, reception history, Slovak music, Literaturoper, Tolstoy

After 1918 one of the issues in the context of the formation of Slovak high culture in the newly established Czechoslovakia was the foundation of a national school in music composition. The assignment was part of the official concept of identity and status of Slovaks in the new state. And it was demanding. The parameters of Slovak art music - an entity which had yet to emerge - were quite clearly determined. It had to feed upon Slovak musical heritage in an ethnic sense - that means from Slovak folk music, preferably from its older, modal strata. It had to demonstrate

1. The present study was supported by the Slovak Research and Development Agency (APVV) under the contract No. APVV-14-0681. 
the affinity of Czechs and Slovaks and show the development patterns which came into play in Czech music history. ${ }^{2}$ Slovak music had to be modern, up to date, it had not to seem backward in comparison to other nations' music. At the same time, however, Slovak music could not be too modern, because that might disgust the newly emerging Slovak audience. ${ }^{3}$

If we look into Slovak musicological writings, we will learn that the project of modern Slovak music seems to have been highly successful. If I am asked about it, I might say: yes, aside from numerous pieces of rather local significance, and which develop the national-conservative aesthetic concept that has been named "Slovak modernism" by Ladislav Burlas, ${ }^{4}$ also individual valuable works have been created, which pass the test of time and represent substantial contributions to European music culture. But if we look, finally, into books on the history of European music, modern Slovak music is nearly non-existent. There are reasons for that, neither exclusively aesthetic nor just political ones. The low intensity of the reception of Slovak music is indeed - if we do not confine to weep and lament over it - an interesting question of music history.

The European reception of music composed by Slovak composers in the twentieth century has had two peaks. The first one was managed by the nazified Universal Edition during the Second World War: effective pieces by the young composer Eugen Suchoň (1908-1993), especially his Baladická suita (Balladic Suite) for orchestra (1935) and Žalm zeme podkarpatskej (Psalm of the Sub-Carpathian Land), cantata for tenor, chorus and orchestra (1938), which combine postromantic excitement and imagery with chromatic-modal harmony derived from extended tertian chords, ${ }^{5}$ have been performed by both the Berlin and Vienna Philharmonic Orchestras under the baton of Karl Böhm. This success was achieved at times of supported cultural exchange between the German Reich and its ally countries including Slovakia. ${ }^{6}$ But Suchoň was surely one of the better among contemporary composers remaining available after the elimination of the "degenerate" avant-garde in the Reich and its allies. The musical means he used do not go far beyond Richard Strauss, and his misty, balladic symphonic narrations, oscillating between eroico and doloroso, not only complied with the self-image

2. See Miloš Zapletal, "Martyrdom and Moral Perfection: Zdeněk Nejedlý's Conception of the Great Czech Composer," in Musicologica Istropolitana, vol. 12: Paths of Musicology in Central Europe, ed. Marcus Zagorski and Vladimír Zvara (Bratislava: Univerzita Komenského, 2016), 69-90. 1996).

3. See Nada Hrčková, Tradicia, modernost’ a slovenská hudobná kultúra 1918-1948 (Bratislava: Litera,

4. Ladislav Burlas, Slovenská hudobná moderna (Bratislava: Obzor, 1983).

5. See Branko Ladič, “Transformations of Folklorism in 20th-Century Slovak Composition,” Studia Musicologica 56/4 (December 2015), 367-395.

6. On the role of Universal Edition in the promotion of contemporary music at that time, see Kim H. Kowalke, "Music Publishing under the Nazis: Schott, Universal Edition, and their Composers," in Music and Nazism, ed. Albrecht Riethmüller and Michael Kater (Laaber: Laaber, 2003), 170-318. 
TABLE 1 List of productions of Cikker's operas

\begin{tabular}{|l|l|}
\hline \multicolumn{1}{|c|}{ Title } & \multicolumn{1}{c|}{ Production } \\
\hline Juro Jánošík & $\begin{array}{l}\text { Bratislava, 1954, 1961, 1972; Ljubljana, 1963; Banská Bystrica, 1968, 1984, } \\
\text { 2016; Plzeň, 1968; Brno, 1978; Liberec, 1983 }\end{array}$ \\
\hline Beg Bajazid & $\begin{array}{l}\text { Bratislava, 1957; Košice, 1957; Prague, 1957; Wiesbaden, 1958; Dresden, } \\
\text { 1959; Altenburg, 1960; Szeged, 1963; Banská Bystrica, 1966 }\end{array}$ \\
\hline Mister Scrooge & Kassel, 1963; Bratislava, 1963, 2011; Košice, 1984; Banská Bystrica, 1997 \\
\hline Vzkriesenie & $\begin{array}{l}\text { Prague, 1962; Bratislava, 1962, 1976, 1996; Gera, 1962; Halle, 1962; } \\
\text { Košice, 1963; Stuttgart, 1964; Wuppertal, 1964; Göteborg, 1965; Brno, } \\
\text { 1965; Stralsund, 1966; Braunschweig, 1969; Lübeck, 1969; Altenburg, } \\
\text { 1970; Wiesbaden, 1972; Bielefeld, 1972; Schwerin, 1973; Antwerpen, } \\
\text { 1974; Bern, 1979; Münster, 1985; Bremerhaven, 1993 }\end{array}$ \\
\hline Hra o láske a smrti & Munich, 1969; Wuppertal, 1969; Bern, 1971; Bratislava, 1973; Prague 1983 \\
\hline Coriolanus & Prague, 1974; Mannheim, 1974; Weimar, 1977 \\
\hline Rozsudok & Bratislava, 1979; Erfurt, 1979; Braunschweig, 1981; Opava 1983 \\
\hline $\begin{array}{l}\text { Obliehanie } \\
\text { Bystrice }\end{array}$ & Bratislava, 1983 \\
\hline Zo života hmyzu & Bratislava, 1987 \\
\hline
\end{tabular}

of Slovaks - the Slovak myth ${ }^{7}$ - but also fitted well in the conservative concept of modern music valid in Germany at the time, consisting of such composers as Paul Graener, Rudolf Wagner-Régeny and Werner Egk.

In this paper, I would like to discuss the second peak in the history of the reception of Slovak music: the success of the operas composed by Ján Cikker (1911-1989) after the Second World War, especially in the two German states (see Table 1). This started with the production of Cikker's opera Beg Bajazid (Prince Bayezid; composed from 1955 to 1956). This "rescue opera" about the incursions of Turks in Upper Hungary in the sixteenth century was premiered in 1957 at the Slovak National Theater, and one of the performances was attended by Dr. Fritz Oeser, an associate of the West German Bärenreiter music publishing house. Due to his effort and the effort of Bärenreiter's owner Karl Vötterle, Beg Bajazid was staged as early as in 1958 in West-German Wiesbaden. The header in the local newspaper proclaimed, as Cikker's widow told me 50 years later, that "Cikker has lifted the Iron Curtain" ("Cikker hat den Eisernen Vorhang gelüftet"). I never found the article containing this sentence, although I have collected the reviews of Cikker's works systematically. But the slogan was perhaps not just a personal myth of Mrs. Cikker; the success of the new opera from beyond the Iron Curtain - in times when the cultural exchange between West and East was still moderate - has indeed received very positive acclaim. The international career of the

7. See Vladimír Zvara, “Randbemerkungen zu den Wandlungen der Kategorie des 'Slowakischen' in der slowakischen Musik," in Musicologica Istropolitana, vol. 12: Paths of Musicology in Central Europe, ed. Marcus Zagorski and Vladimír Zvara (Bratislava: Univerzita Komenského, 2016), 91-110. 
opera composer Ján Cikker skyrocketed after that and reached its peak in the late 1960s, especially with his opera Vzkriesenie (Resurrection), composed from 1959 to 1961 after Tolstoy's novel of the same title. This was his fourth opera and his second Literaturoper, based on a classical literary work; the previous one, Mister Scrooge, composed from 1958 to 1959, was an operatic dramatization of Dickens's novel Christmas Carol.

Ján Cikker embodies several paradoxes of his time and place. His surname is of German origin (Zicker), and was Magyarized in its orthography in the nineteenth century (Czikker), and then de-Magyarized and quasi Slovakicized after the First World War (Cikker - the characteristic Hungarian " $\mathrm{Cz}$ " had to be eliminated, without change of pronunciation). He was born in the Central Slovakian town of Banská Bystrica, named Besztercebánya at the time of Habsburg-dominated Hungary (in German, Neusohl). He was a proud Slovak patriot, who at the same time was familiar with both the Hungarian and German languages and cultural traditions. During World War II he participated in the resistence; however, after the communist coup of 1948 he was called an enemy of the people and lost his job as an opera dramaturg at the Slovak National Theater. He was a faithful Catholic and never joined the party, but he composed a "people's cantata" named Zdravica Stalinovi (Greetings to Stalin) in 1949. ${ }^{8}$ And, ultimately - and this is no paradox anymore - as composer he reached international success just after he departed from the preferred topics and musical aesthetics of the national school.

He did so in the genre what Carl Dahlhaus called Literaturoper. ${ }^{9}$ The conservatively modern Literaturoper after World War II, represented by the works of Gottfried von Einem, Hans Werner Henze or Sándor Szokolay - I intentionally do not mention Bernd Alois Zimmermann nor Wolfgang Rihm -, is an interesting phenomenon in both the composition and reception of opera. Concerning the basic configuration of story and music, and of human voice and orchestra, it harkens back mostly to the model of Richard Strauss's operas, while in dramatic structure and in capturing the reality of the plot also newer concepts are applied, mixed with elements of traditional opera dramaturgy. In their musical language, most of afterwar Literaturopern do not fulfill the requirements of New Music, but, on the other hand, they go considerably far beyond what is pleasant to an opera lover's ear. Nevertheless, the postwar audience, especially in Germany, largely accepted this uneasy music, as long as it was in the service of great stories. And this audience, still flying the flag of bourgeois culture, was ready to undergo certain suffering to keep in touch with modern art.

8. For the story of Cikker's life, see Michal Palovčik, Ján Cikker v spomienkach a tvorbe (Bratislava: H plus, 1995).

9. For the concept of Literaturoper, see Carl Dahlhaus, "Zur Dramaturgie der Literaturoper," in Für und wider die Literaturoper. Zur Situation nach 1945, hrsg. Sigrid Wiesmann (Laaber: Laaber Verlag, 1982), 147-163. 
Cikker's Vzkriesenie, the piece I will focus on in this paper, is a foremost opera of the composer's mature period. Its genesis was influenced by the stress and depression that resulted from a ban on the first production of Mister Scrooge in 1959 by the communist government, and a consecutive performance ban on Cikker's music, which would last two years. ${ }^{10}$ On the other hand he was stimulated by the success of Beg Bajazid in Germany and encouraged by his publisher Bärenreiter to continue working. Vötterle and Oeser became Cikker's friends, and Oeser also found his artistic collaborator and - as I discovered in the composer's estate - the secret co-author of the libretto of Vzkriesenie, and of the highly acclaimed concept of theatrical transformation of Tolstoy's story into the opera's storyline (see Table 2). ${ }^{11}$

\section{TABLE 2 Outline of Cikker's Vzkriesenie}

\begin{tabular}{|l|l|l|}
\hline Act & Part & Plot \\
\hline \multirow{3}{*}{1} & Scene 1 & Nekhlyudov seduces Katyusha. \\
\cline { 2 - 3 } & Intermezzo 1 & $\begin{array}{l}\text { Katyusha's dream. Nekhlyudov's departure, the child, the aunts turn her } \\
\text { out of the house. }\end{array}$ \\
\cline { 2 - 3 } & Scene 2 & The brothel. The murder of Smelkov. \\
\hline 2 & Scene 3 & $\begin{array}{l}\text { The trial. Katyusha is sentenced to eight years of forced labour. } \\
\text { Nekhlyudov recognizes her. }\end{array}$ \\
\cline { 2 - 3 } & Intermezzo 2 & Nekhlyudov tortured by his memories. \\
\cline { 2 - 3 } & Scene 4 & $\begin{array}{l}\text { A prison yard. Nekhlyudov has come to visit Katyusha. She dismisses } \\
\text { him. Her outrage spreads to her fellow prisoners. }\end{array}$ \\
\hline \multirow{3}{*}{3} & Scene 5 & $\begin{array}{l}\text { Nekhlyudov again meets Katyusha and asks for her hand. She tells him } \\
\text { she is already promised to Simonson. }\end{array}$ \\
\cline { 2 - 3 } & Intermezzo 3 & $\begin{array}{l}\text { The voices of Katyusha and Nekhlyudov overlap. Katyusha bids farewell } \\
\text { to Nekhlyudov. Her illness advances. }\end{array}$ \\
\cline { 2 - 3 } & Scene 6 & $\begin{array}{l}\text { Siberian steppe. Convoy of prisoners. Katyusha suffers fainting spells. } \\
\text { Nekhlyudov brings pardons for her and for Simonson. Katyusha dies. }\end{array}$ \\
\hline
\end{tabular}

It is not just the production list of Vzkriesenie that is impressive, containing productions at major opera houses like those in Prague and Stuttgart. It is also notable that some of the productions had many performances, much more than most contemporary operas in the twentieth century. In Wuppertal Vzkriesenie was performed 24 times in a single season..$^{12}$ The premiere of Günther Rennert's staging in Stuttgart, with Lore Wismann and Carlos Alexander in the main roles,

10. Vladimír Zvara, Ján Cikker: Vzkriesenie. Genéza, osudy a interpretácia operného diela / "Auferstehung.” Entstehung, Wirkung und Interpretation der Oper (Bratislava: Veda, 2000), 129.

11. See Vladimír Zvara, "Ján Cikker und Fritz Oeser. Zur Geschichte einer verschwiegenen künstlerischen Zusammenarbeit," in Musicologica Istropolitana, vol. 5, ed. Marta Hulková (Bratislava: Univerzita Komenského, 2006), 87-98.

12. "Kein Pathos. Ein Interview mit dem Regisseur Kurt Horres," in Ján Cikker: "Auferstehung". Programmheft (Wiesbaden: Hessisches Staatstheater, 1972), 314-315. 
was held on 3 May 1964; the production was recorded live and broadcasted by the West German TV company ZDF in 1967, and in December 1968 it was still in the repertoire. ${ }^{13}$ Rennert also asked Cikker to let him stage the world premiere of his next opera, which would be Cikker's Hra o láske a smrti (The game of love and death) after Romain Rolland's play Le Jeu de l'amour et de la mort. ${ }^{14}$ Its premiere took place at the Munich Festival (Münchner Festspiele) 1969. The festival poster was dominated by facsimile signatures of Beethoven, Mozart and Cikker.

Regarding the international press reviews about Vzkriesenie from the 1960s, most of them were simply flattering. Already the headlines were thrilling: "Auferstehung" ein Ereignis (Resurrection - a sensation), ${ }^{15}$ Modell für modernes Musiktheater (Model for the modern music theater); " The piece was praised as the most significant Czechoslovak opera after Janáček, and the composer as a "serious competitor of Shostakovich." ${ }^{18}$ Vzkriesenie was called "a modern repertoire opera", which "mediates between the requirements of specialists and the expectations of the broad audience." ${ }^{19} \mathrm{Or}$, as stated by another critic, "in the opera repertoire it is closing the long-standing gap between the conservative taste of audiences and the respective avant-gardes". ${ }^{20}$

Conservative reviewers express also their aversion, or even aggression towards the avant-garde in their reviews about Vzkriesenie. "Cikker loathes the sterile avant-gardism ... so the younger colleagues might name him a dry conservative." However, the result is that his

Vzkriesenie ... found its way into the repertoire of many opera houses. ... What is the use of a very smartly written opera, which will be laid in a box after its first performance and will rest there ingloriously? ${ }^{21}$

13. Zvara, Ján Cikker: Vzkriesenie, 282.

14. Before Hra o láske a smrti, Cikker worked on an unfinished opera Meteor (The meteor) after Peter Karvaš's play of the same title. He abandoned the project after a negative assessment of the libretto made by Oeser and Rennert. See Zvara, "Ján Cikker und Fritz Oeser." 1969).

15. “'Auferstehung' ein Ereignis. Premiere im Staatstheater,” Braunschweiger Presse (29-30 March

16. Heinz Ludwig Schneiders, "Modell für modernes Musiktheater. Cikkers Oper 'Auferstehung' in der Inszenierung von Friedrich Petzold" [published in an unidentified newspaper; the review refers to the staging in Braunschweig].

17. Edinburgh Evening News and Dispatch (19 August 1994); after a guest performance of the Prague National Theater.

18. Kurt Honolka, "Erniedrigte und Erhobene. Westeuropäische Erstaufführung in Stuttgart: Ján Cikkers Oper 'Auferstehung,", Stuttgarter Nachrichten (5 May 1964); Ernst Thomas, "Tod auf dem Marsch nach Sibirien. Ján Cikkers 'Auferstehung,', Frankfurter Allgemeine Zeitung (12 May 1964).

19. “'Auferstehung' ist ein Werk, das zwischen den Ansprüchen der Fachleute und den Erwartungen des breiten Publikums vermittelt." Claus-Henning Bachmann, "Dramatische 'Auferstehung'. Ján Cikkers Oper nach dem Roman Tolstois in Stuttgart aufgeführt,” Frankfurter Rundschau (7 May 1964).

20. "Im Opernrepertoire schließt sich dabei die Lücke, die seit langem zwischen dem konservativen Publikumsgeschmack und der jeweils modernsten Avantgarde besteht." "Die surreale Landschaft der russischen Seele: Ján Cikkers Oper ‘Auferstehung' - Westeuropäische Erstaufführung,” Die Welt (7/8 May 1964).

21. N. N., "K.V.O. - Opstanding," Pallietence [Antwerpen] (21 February 1974). 
That means it is still possible to write pieces for music theater without cheap concessions and without committing to the snobbish attitude of being contemptuous of the listener and flirtatious with the fashionable tristesse. ${ }^{22}$

Another reviewer compares Cikker's opera to what he calls "semi-modernism" (Halbmoderne) and stresses the composer's courage to the "wholeness" (Ganzheit), meaning the courage to an operatic narration of the whole story with its dramatic and psychologic complexity, and also with its pathos and transcendence:

... compared with the works of Martinu or the late Prokofiev, this opera is a genuine masterpiece. It by no means shows that annoying artisan attitude, the impotence of semi-modernism, which refuses to admit its own incapacity for the wholeness .... ${ }^{23}$

In my book about Vzkriesenie ${ }^{24}$ I tried to connect the genesis of the piece, its musical and dramatic structure, and its international reception as conveyed through the reviews published mostly in the 1960s and 1970s. One of the interesting conclusions I came to is that the views on Vzkriesenie and their transformation reveal a general change of taste, which is clearly evident in these reviews and can be presumed to be shared, with some time delay, by the opera audience too. This change of taste would gradually lead not just to a decrease in the popularity of Cikker's operas, but also to a general decline of conservatively modern Literaturopern, with their music manoeuvring between Richard Strauss and New Music, and with their various forms of - modernised - psychological realism.

As shown above, Cikker first appeared as a hero of aesthetic centrism in the Western reviews. But this would change soon. It would be the same qualities of his style praised by his admirers for which he would be criticized a few years later. It was enough to change slightly the perspective. Mediation turned out to be a compromise. In - increasingly frequent - critical reviews, Cikker himself was regarded as "semi-modernist," and Vzkriesenie was referred to as "everyday opera"

22. "Es ist also auch heute noch möglich, ohne alle billigen Konzessionen Werke fürs Musiktheater zu schreiben, die sich nicht mit der hörerverachtenden Attitüde des Snobs, mit dem Liebäugeln nach der modischen Tristesse begnügen." Honolka, "Erniedrigte und Erhobene."

23. “... gemessen an den Produktionen etwa Martinůs oder des späten Prokofieff ist diese Oper ein reines Meisterwerk. Es fehlt ihr ganz die leidige kunstgewerbliche Attitüde, die Impotenz der Halbmoderne, die sich ihr Unvermögen zur Ganzheit nicht eingestehen will." Bachmann, "Dramatische 'Auferstehung,."

24. Zvara, Ján Cikker: Vzkriesenie. 
EXAMPLE 1 Vzkriesenie, final scene

(vocal score; Bratislava: Slovenský hudobný fond, 1961)
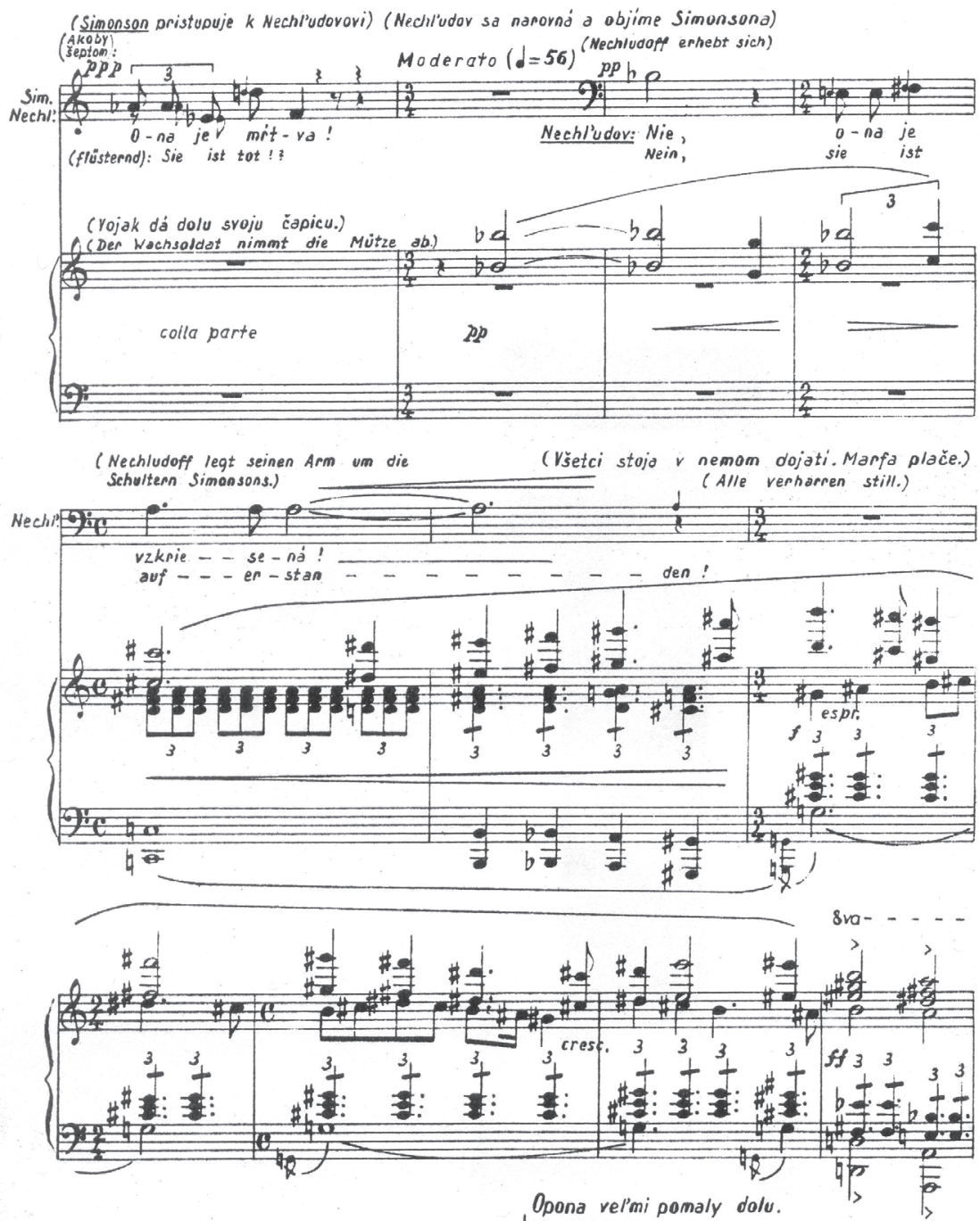

Opona vel'mi pomaly dolu. I Vorhang lanasam zu.

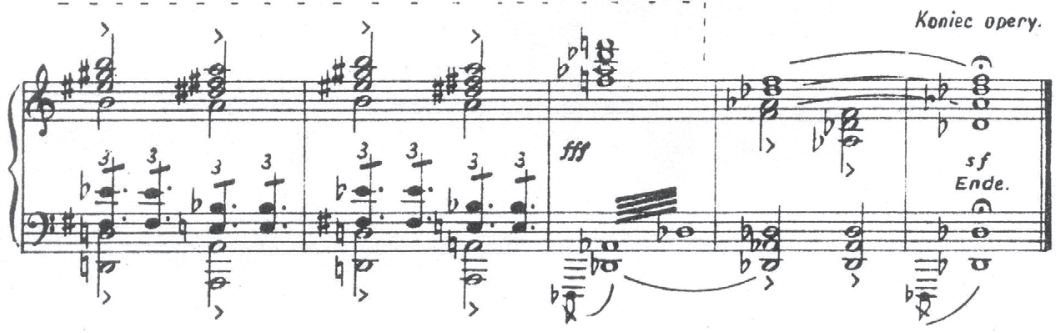


(Gebrauchsoper), ${ }^{25}$ "a 'verismo' thriller in a didactic manner" (Verismoreißer im Lehr-Ton), ${ }^{26}$ or "a Puccini-esque melodrama" (puccinihaftes Rührstück). ${ }^{27}$

The criticism addressed particularly the end of the opera, in which Oeser and Cikker departed from Tolstoy, and which in their version is quite strongly aligned with operatic convention in both text and music. The convoy of prisoners (the chorus) has left; on the stage remain just Katyusha, Count Nekhlyudov, Katyusha's fellow prisoner Simonson, the elderly couple Pyotr and Marfa, and one soldier. In the bleak snowy Siberian landscape the farewell ensemble resounds. Katyusha intones a song from the first scene, which symbolizes the state of innocence to which she has now returned. Then Katyusha dies in Count Nekhlyudov's arms. Simonson whispers: "She is dead!", and Nekhlyudov solemnly disagrees: "She is resurrected!" The orchestra plays bitonal chords representing the church bells (see Example 1, mm. 11-13) not unlike the end of Risurrezione, Franco Alfano's veristic opera on the same literary model. And then the sun comes out from behind the clouds: the cathartic D-flat major chord in tutti. The major triad, which till now was only hinted at in Cikker's score, or used in a whimsical verfremdet manner, as in the cancan in the Brothel Scene, sounds at the end of the opera for the first and only time in a shining, emphatic form - salvation in and through music.

The idealistic and affirmative end of the opera is not only what it seems at first sight - a traditional, sentimental opera ending à la Traviata, Manon Lescaut or La Bohème, with an unfortunate heroine dying in her lover's arms. It is prepared by a thoroughly durchkomponiert course of play, in which resurrection represents a metaphor of the spiritual maturation of both Katyusha and Nekhlyudov. Nevertheless, in the end of the opera as genre triumphs over Tolstoy's sober enlightened realism, and also over modernist poetics. In his letters about the libretto of Vzkriesenie, Oeser sometimes warned Cikker not to be "too operatic" (zu opernhaft). ${ }^{28}$ In this ending, however, the inclination of both co-authors to traditional opera is clear and obviously deliberate, and it is now Oeser who urges the composer to put the central couple in the limelight, even though with a quite sophisticated dramaturgical justification:

So wie die Handlung nun geführt ist müßte nach meinem Gefühl nicht Pjotr, sondern Nechludow die Schlußworte sagen. Welche Schwierigkeiten der Operntitel "Auferstehung" mit sich bringt, ist klar, weil es sich dabei um ein-

\footnotetext{
25. Paul Müller, "Eine Gebrauchsoper nach Tolstoi. ‘Auferstehung' von Ján Cikker im Wuppertaler Opernhaus," Rheinische Post (14 September 1964).

26. Jörg Loskill, "Ein Verismo-Reißer im Lehr-Ton. Ján Cikkers 'Auferstehung' in Münster," Opernwelt 26/6 (1985).

27. Gotthard Schmidtke, “Ján Cikkers Oper 'Auferstehung'. Erstaufführung im Staatstheater Braunschweig," Braunschweiger Zeitung (29 March 1969).

28. Oeser's letter to Cikker, written on 28 March 1960. Carbon copy. Múzeum Jána Cikkera, Bratislava (without inventory number). Quoted in Zvara, Ján Cikker: Vzkriesenie, 225.
} 
nen theologischen Begriff handelt, der schon von Tolstoi in einem übertragenen Sinne verwandt wird. Es ist richtig, dass mit den letzten Worten: "Sie ist auferstanden" auf den Titel Bezug genommen wird, sonst würde am Ende manchem Zuhörer gar nicht klar werden, warum die Oper so heißt. Ich glaube, warum bei dem Schicksalsweg der beiden Menschen von Auferstehung geredet werden kann, tritt jetzt klarer heraus als vorher, vor allem bei Nechludow, dessen Zeichnung in der ersten Textgestaltung etwas verschwommen wurde, zu sehr nur Liebhaber bei der sterbenden Geliebten wie der Alfred der "Traviata" oder Des Grieux der "Manon." Es tritt (natürlich nur, wenn ihn die Musik entsprechend zeichnet) nun hervor, daß Nechludow sich von einem leichtfertigen, unverantwortlichen jungen Menschen durch eine harte und oft demütigende Buße zu einem reifen, klaren, verantwortungsvollen Manne entwickelt, in dem Kraft und Güte einander nicht ausschließen. Deshalb muß man am Schlusse das Gefühl haben, daß er nicht verzweifelt, sondern den einmal als richtig erkannten Weg weiter gehen wird; aus diesem Grunde scheint mir eben auch richtig zu sein, daß ihm die Erkenntnis kommt, daß Katuscha nicht "tot" sei: indem er das ausspricht, erkennt man, daß das gleiche von ihm gesagt werden kann. ${ }^{29}$

(As the course of play is conducted now, it must be not Pyotr but Nekhlyudov who will say the closing words. It is clear, which difficulties the opera title "Resurrection" implies. It is a theological concept, which is used in a figurative sense already by Tolstoy. It is right that the final words "She is resurrected" refer to the title, otherwise many listeners will not realize why the opera bears this title. I think now is clearer than before why it is legitimate to speak of Resurrection in relation to the destiny of both figures, especially of Nekhlyudov, whose outline in the preliminary text version was quite blurry, too much a mere lover with his dying beloved like Alfredo in "La traviata" or Des Grieux in "Manon." Now it is obvious [provided the music describes him accordingly] that Nekhlyudov transformed through tough and often humbling penance from a careless, irresponsible young man into a mature, direct, responsible man, in which power and goodness do not exclude each other. Therefore there has to be a feeling at the end that Nekhlyudov will not despair, but will continue going the way he has recognized as right. This is why it seems to me to be correct, when he realizes that Katyusha is not "dead": through the fact that he pronounces it, we can see that the same can be said about him.)

It was the end of Vzkriesenie that often seemed to be a key problem of the piece to progressivist critics in the West. They labeled it as "flat, harsh, poster-like, mannered" (flach, plakat-grell, manieriert), and as the "Achilles heel of the piece" 
("Achillesferse" des Werks), where "the major issue of guilt and atonement, of compassion for those who are trampled underfoot, trickles away in a touching idyll." "Cikker's purely harmonic act endings do not attain the persuasive power of non-reflected simplicity or transcendence in this country [hierzulande]; they appear rather as unnecessary compromises." ${ }^{31}$ In this sentence the critic Friedrich Hommel (born in 1929) gets to the heart of the issue, contradicting unknowingly (not knowing of his co-autorship) his fellow countryman Fritz Oeser (born in 1911). "Hierzulande" (that means actually: in the West), the traditional operatic connection of transcendence with enjoyment of "private feelings" (Privatgefühle, a term coined by Immanuel Kant) is now - at least in newly composed works turning aesthetically implausible and therefore dramatically unconvincing. Time would go on to confirm this maxim of geopolitical aesthetics. Cikker, and even more his co-librettist - his Hofmannsthal, so to speak - did try to reflect the taste and the expectations of their target group, the contemporary opera audience, without, hovewer, anticipating the already mentioned change of taste. Vzkriesenie, with its exceptionally well-documented genesis and its extensive reception, sheds light on this interesting shift in opera reception and appreciation in Western Europe.

The reviews from the German Democratic Republic represent a separate topic. Of course their authors show due respect to a composer from brotherly Czechoslovakia and praise his "challenging but profound" opera. ${ }^{32}$ Some of them take the class conflict theory as their starting point, arriving at quite odd conclusions:

Im Mittelpunkt der tragischen Handlung steht das einfache Bauernmädchen Katerina Maslowa, Katuscha genannt, das dem 'finsteren Reich' des zaristischen Despotismus zum Opfer fällt ... . Zu spät kommt die Wandlung Nechludoffs zu einem wirklichen Menschen, denn Katuscha, die inzwischen von dem politischen Gefangenen Simonson über das Los ihrer Klasse unter der zaristischen Herrschaft aufgeklärt ist, stirbt in den Armen Nechludoffs. ${ }^{33}$

(In the center of the tragic plot there is the simple peasant girl Katerina Maslova, called Katyusha, who falls victim to the "dark empire" of the tsarist despotism ... Nekhlyudov's transformation into a true man comes too late, because

30. "Da versickert das große Thema von Schuld und Sühne, vom Mitleid mit der getretenen Kreatur im rührenden Idyll.” Alfred Mayerhofer, "Im Inferno menschlichen Leids. Viel Beifall für Ján Cikkers “Auferstehung', die erste Opernpremiere der Spielzeit," General-Anzeiger [Saar?] (14 September 1964).

31. "Seine rein harmonischen Aktschlüsse erreichen hierzulande nicht mehr die Überzeugungskraft unreflektierter Einfachheit oder Verklärung; sie wirken eher wie unnötige Kompromisse.” Friedrich Hommel, “Tolstois Traviata. Cikkers 'Auferstehung' in Stuttgart,” Stuttgarter Zeitung (5 May 1964).

32. Peter Schua, "Darstellung psychischer Vorgänge. Ján Cikkers Oper ‘Auferstehung' im Mecklenburgischen Staatstheater Schwerin" [published in an unidentified newspaper], (17 May 1973).

33. F. Diesel, “Ján Cikkers 'Auferstehung' großer Erfolg. Weihevoller Auftakt der Geraer Theaterfestwoche im Großen Haus," Thüringer Tageblatt [Weimar] (10 October 1962). 
Katyusha, meanwhile made aware of her social class's fate under Tsarism by the political prisoner Simonson, just dies in Nekhlyudov's arms.)

Some reviewers stress the strength of the "simple Russian people," which seems to be a consequence of the specific East German reception of Tolstoy. This perspective might have influenced also the staging concepts of Vzkriesenie in the German Democratic Republic. For instance, the stage directors Helmut von Senden (in Altenburg, 1970) and Joachim Robert Lang (in Schwerin, 1973) let the chorus (the prisoners) stay on the stage till the end to witness Katyusha's death. It should be noted, however, that the West German director Günther Rennert was the first to do this, in his Stuttgart production in 1964, letting the chorus even repeat its resting song from the beginning of the last scene at the very end. ${ }^{34}$ Vzkriesenie has been subjected to open criticism from a Marxist perspective only one time, namely by the Czech musicologist Jiři Bajer, who was bothered by the end of the opera too:

In Cikker's opera Resurrection is associated with the death of Katyusha. ... Simonson bows down to her and says: she is dead. Nekhlyudov with visionary emphasis: she is resurrected. The orchestra plays the formidable final chord. This cannot be a satisfying denouement of the drama. This ending devalues the dramatist's striving for a true depiction of the great human fight for justice and happiness. The meaning and the progressive value of Tolstoy's novel was in the way how he, apart from the destiny of both protagonists, described and strongly condemned the severe methods of the tsarist regime. That was why Lenin ... Chekhov and many others esteemed him. ... What good is it that we admire the composer's warm affection for the humiliated and tortured Katyusha and for the whole humanity? This love, this humanism are like a flower which, as we know, will bring no fruit, and it is these fruits which represent the purpose of arts. Cikker has created a work of artistic power equal to the literary model, but on the other hand - I am sorry to say that - he is intellectually falling below Tolstoy. ${ }^{35}$

Another issue often discussed by the critics was the dramatization of Tolstoy's novel in Cikker's Vzkriesenie. The general outline of the opera (Table 2) discloses one of its most interesting features: how Cikker and Oeser select episodes from the novel's epic flow and how they assemble the storyline of the opera. In this respect, the orchestral music of Vzkriesenie plays an important role, especially that of the interludes, strikingly eloquent (Wagner would say beredt) and exhibit-

34. Zvara, Ján Cikker: Vzkriesenie, 281, 288, and 291.

35. Jiři Bajer, "Vzkř́išení v záhrobním životě," Divadelní noviny 6/24 (1962). 
ing a specific kind of "dispersed subjectivity" of musical narrative. ${ }^{36}$ The orchestra in Cikker's opera seems to be an element from which the scenes and the intermezzos emerge, representing the reality of the plot in two different ways. While the scenes are descriptively realistic, real-time tableaux, the intermezzos summarize in dreamlike time-lapse what happens between the scenes. The alternating of scenes and intermezzos gives a certain rhythmic structure to the storytelling. And the realism of the scenes is refreshingly spiced-up by less realistic, slightly verfremdet intermezzos. To watch the two main characters wandering through scenes and intermezzos, with their changing milieu and code, is somewhat like an optical effect, an attraction per se.

The power of the intermezzos was obvious already for the team of the world premiere production in Prague (1962) and it served as a starting point for its concept. The stage director Karel Jernek and the set designer Zbyněk Kolár extended the atmosphere of the intermezzi, their mutable and immaterial nature, over the whole storyline, placing large sections of action on the huge labyrinthine construction of lanes and stairs hanging above the stage (Plate 1). As the stage director put it, on this construction Katyusha "lost the ground under her feet", held on the parapet, "not to be thrown down by the hostile staircase", "passed through her life like through a labyrinth of jails, through roaring hypocrisy and perfidy, looking for her mysterious prosecutor with the same hopelessness as the hero of Kafka's Trial." ${ }^{37}$ According to Norbert Ely, the stage director Kurt Horres also staged Vzkriesenie "towards the intermezzi" in Wiesbaden, whereby "not only there were no cracks between different levels of reality, between presenting reality and reflecting upon it; the reality itself was permeated by reflection." 38

Sometimes the borderline between reality and dream is quite blurry in Vzkriesenie, and relapses of the dream intrude into the scenes. An interesting example is opening of the prisoners' chorus, scene 4 (Example 2). In the prison yard, before and during the dawn, the prisoners sigh, whisper, speak and sing in their unquiet sleep. The action takes place in semi-darkness, which may represent the morning dawn but at the same time suggests an indefinite time and space, a transition from the dreamlike intermezzo to the following realistic scene. Cikker's early libretto sketch implied however the afternoon time, prisoners singing "sadly about their longing for freedom, the outside world and lost happiness." ${ }^{39}$ Oeser reacted unambigously: this sort of a "Fidelio chorus," he wrote, would be inappropriate.

36. See Carolyn Abbate, Unsung Voices. Opera and Musical Narrative in the Nineteenth Century (Princeton: Princeton University Press, 1996), 14.

37. Karel Jernek's essay in Ján Cikker: Vzkříšení. Rozbor inscenace Národního divadla v Praze (Praha: Divadelní ústav, 1968), 19.

38. Norbert Ely, “'Auferstehung' oder der schmale Weg zu sich selbst. Ján Cikkers Oper in der Neuinszenierung von Kurt Horres," Wiesbadener Kurier (27 March 1972).

39. Zvara, Ján Cikker: Vzkriesenie, 174. 
Plate 1 Alena Míková (Katyusha) in the Third Intermezzo of Vzkriesenie (Prague National Theatre, 1962; Photo: Dr. Jaroslav Svoboda)

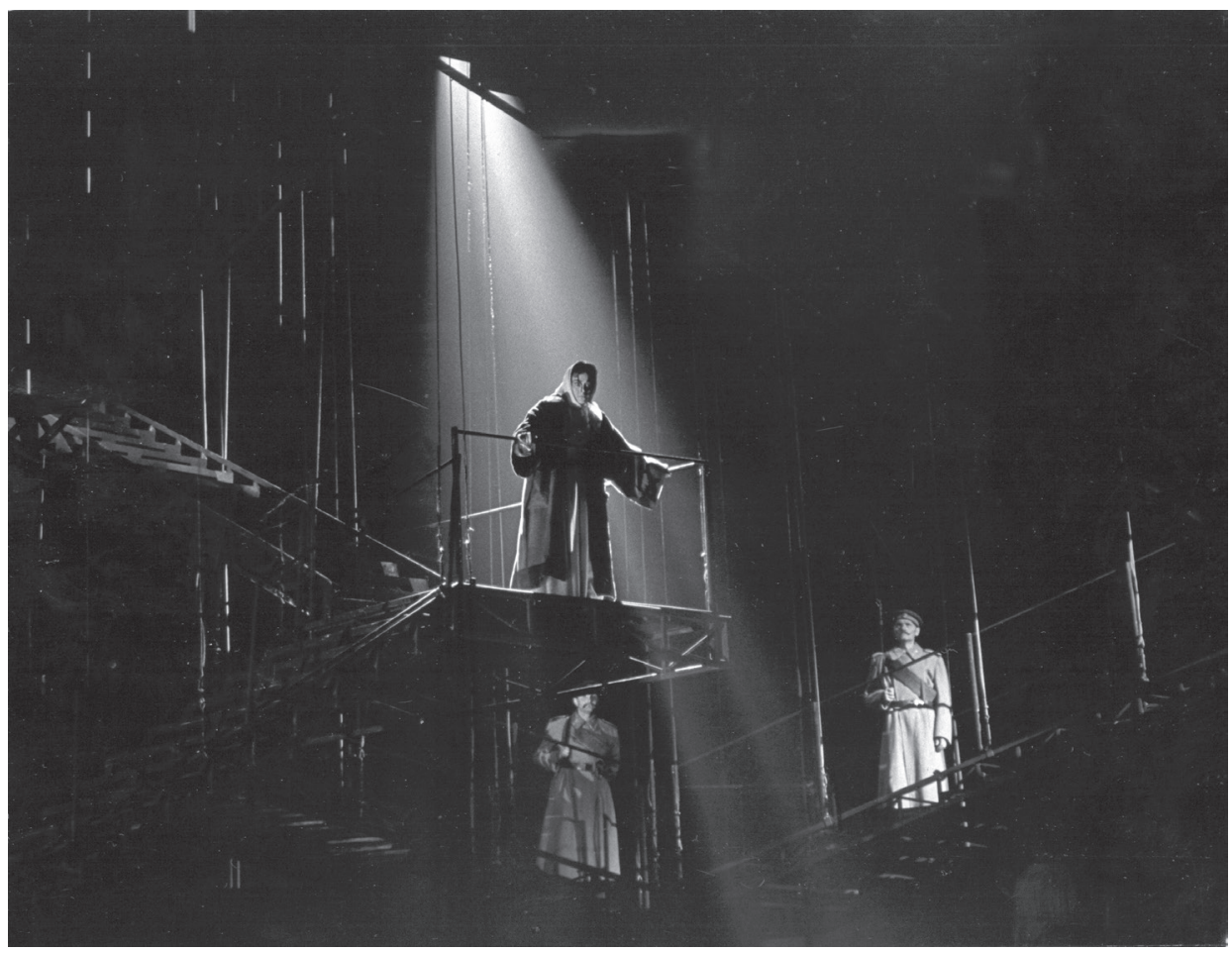

Dear Jan, once again the voice of compassion prevails in your writing. And it does not appear clearly enough how much the individual is degraded by being jammed in a narrow space among the masses. Through that alone it can be made understandable that in this environment Katyusha moves far away, beyond recognition, from herself, which will be demonstrated at the end of the scene. ${ }^{40}$

In Cikker's music the actually "closed" chorus number is sustained by a funeral march-like rhythmic pulsation. The broad vocal line, emerging gradually from Sprechgesang, strives upwards, against the background of the descending sospiri exposed in imitations in the inner voices. In the vocal lines, traces of major-minor tonality can be detected, while intervallic harmony prevails vertically, with a preference for major seconds and tritones. The scene now in no way evokes the

40. Fritz Oeser's letter to Ján Cikker, 4 January 1960. Carbon copy. Múzeum Jána Cikkera, Bratislava (without inventory number). Quoted in Zvara, Ján Cikker: Vzkriesenie, 215. For the German original, see Facsimile 1. 
FAcsimile 1 Fritz Oeser's letter to Ján Cikker, 4 January 1960

4. Bild

$===x==x==$

1) Wir waren uns einis, das die beiden Gefungnisbegegnungen Nechludows mit Katuscha sehr segensatzlich sein mijten. Dazu gehört, dab die Gefingnisatmosphäre, die Eingesperrtenpsychose in ier ersten Szene stärker spürbar sein muB, als es bis jetzt der Fall ist. A ch hier uberwiegt bei Dir zu sebr die stimme des

Blatt 5 zum Erief an Herrn Prof. Jan Cikker - Bratialava - V. 4.1 .196

\begin{abstract}
Mitleids und komit nicht klar genug heraus, wie sehr das Individuum durch das Eingepferchtsein unter Massen auf engem Raum entwürdgt wirl, - nur dadurch aber kann varstandlich werden, dak Katuscha in ieser Umgebung sich bis zur Unkenntichkeit von Ihrew eigenen Selbst entfernt, wie es der Szenenschlub zeitt. Tolstoi hat das a err eutlich herauspearbeitet, und von seinen $320-$ nen sollte man aie eine nutzen, die die erste Begegnung NachIudows mit Katuscha inmitten eines Massenbesuches zeigt. - Die Entwürdigung, die Nechludow dadurch erfärt, dab er sein Schuldbekenntnis in dem Stimmengewirr car nicht verständich machen kann, ist fur ihn lann der erste heilsame Schritt auf dem wege zur ehrlichen inneren wand Iung abseits blober Selbstbemitleidungogefuhle, und zu zeigen, wie er bis zu seinem innersten Kern blobgelegt wird, ist der Hauptzweck dieser Szene.
\end{abstract}

"Fidelio chorus", but rather the sleeping scene from Berg's Wozzeck, the score of which Oeser had sent Cikker shortly before. Traces of Wozzeck can be detected in the Brothel Scene too, which appears to be inspired by the pub scene from Berg's opera, and, finally, also in the way scenes and intermezzos of Vzkriesenie emerge from the flow of "eloquent" orchestral music.

Ján Cikker's next three operas also were shown on German stages: Hra o láske a smrti, inspired by Alfréd Radok's staging of Romain Rolland's play at the Prague National Theater in 1964, Coriolanus after Shakespeare, and Rozsudok (Verdict), after Kleist's Das Erdbeben in Chili (The earthquake in Chile). In them the creative involvement of Oeser decreases. In the case of Hra o láske a smrti Cikker accepted some of Oeser's conceptual suggestions but decided to write the text alone. To compose an opera about Coriolan was not a good choice at all according to Oeser, and therefore he was not willing to collaborate on it:

Deinen Plan halte ich nicht für vielversprechend, weil mindestens im deutschen Sprachraum Brechts Bearbeitung des Stoffes sich nicht umgehen lässt und auch, weil ich an Deiner Stelle nach 'Bajazid' nicht ein zweites Mal das Problem Mutter - Sohn aufgreifen würde. 
(I do not consider your plan promising because, at least in the German-speaking area, it is impossible to sidestep Brecht's version of the subject and if I were you, I would not tackle the mother-son issue once more after Bayazid. $)^{41}$

It is not known what Oeser's view was on Verdict; it is clear, however, that he is not its co-author.

Cikker's operas written after Vzkriesenie are certainly valuable contributions to the artistic reception of the respective plots, and pièces bien faites in their own way. But the absence of Cikker's "Hofmannsthal" makes evident the composer's limitations as dramatist. Problems accumulate: the lack of the diligent dramaturg's corrective interference in the storytelling, Cikker's aesthetics, which appear increasingly unconvincing to the West German critics, and, in the view of the reviewers who already knew Vzkriesenie, recycling of the same artistic means, without the stringency that had dispelled aesthetic concerns in Cikker's earlier opera. The composer's "old-fashioned goodness," 42 his compassion for his heroes (Stimme des Mitleids), his naive, all-embracing humanism ${ }^{43}$ overwhelm. In Gerhard R. Koch's words, already Hra o láske a smrti has "shown, what is still possible and what is not yet in the framework of this operatic concept [of Vzkriesenie] of indisputably high ethical standard."44 According to Heinz W. Koch, Coriolanus represents a Literaturoper of the old type, "the last word of a chapter that has already been finished." 45 Some reviewers criticize the audiences for their sticking to the "bourgeois music theater" (bürgerliches Musiktheater) ${ }^{46}$ and for their inclination to sentimentality:

Den Münchner Premierengästen muss das Rührstück trotzdem ungeheuer gefallen haben: maßloser Beifall für die Solisten ..., Bravos für den anwesenden Komponisten. Und ich hörte lange nicht, dass so viele Schnupftücher benutzt wurden. Rührseligkeit scheint sich gut zu verkaufen, entsprechend richtet man sich seine Qualitätsansprüche ein. ${ }^{47}$

41. Oeser's undated letter to Cikker. Carbon copy. Múzeum Jána Cikkera, Bratislava (without inventory number). See Zvara, "Ján Cikker und Fritz Oeser," 97.

42. N. N., "'Resurrection' is searingly great," Edinburgh Evening News and Dispatch (19 August 1994).

43. See Gerhart Asche, "Kleist eine Botschaft aufgezwungen. Jan Cikkers 'Das Erdbeben in Chile' in Braunschweig," Opernwelt 22/5 (1981), 4.

44. "Cikkers nächste Oper 'Das Spiel von Liebe und Tod' (nach Romain Rolland) ließ dann deutlich erkennen, was im Rahmen eines solchen Opernkonzepts von unbestreitbar hohem moralisierendem Anspruch noch geht, und was nicht mehr." Gerhard R. Koch, "Wiesbaden: Seelensuche. Ján Cikkers 'Auferstehung,," Opernwelt 13/6 (1972).

45. Heinz W. Koch, "Das letzte Wort eines abgeschlossenen Kapitels? Die deutsche Erstaufführung von Ján Cikkers Oper 'Coriolanus' im Mannheimer Nationaltheater,' Badische Zeitung [Freiburg in Breisgau], (5 November 1974).

46. Hans-Klaus Jungheinrich, "Noch eine Oper zuviel: Ján Cikkers 'Coriolanus' zum ersten Mal in der Bundesrepublik," Frankfurter Rundschau (6 November 1974).

47. Heinz Josef Herbort, "Herrgott, wann wird das ein Ende nehmen? Ján Cikkers 'Spiel von Liebe und Tod' in der Münchner Staatsoper," [published in an unidentified newspaper] (1969). 
EXAmple 2 Vzkriesenie, Scene 4 - prison

(vocal score; Bratislava: Slovenský hudobný fond, 1961)

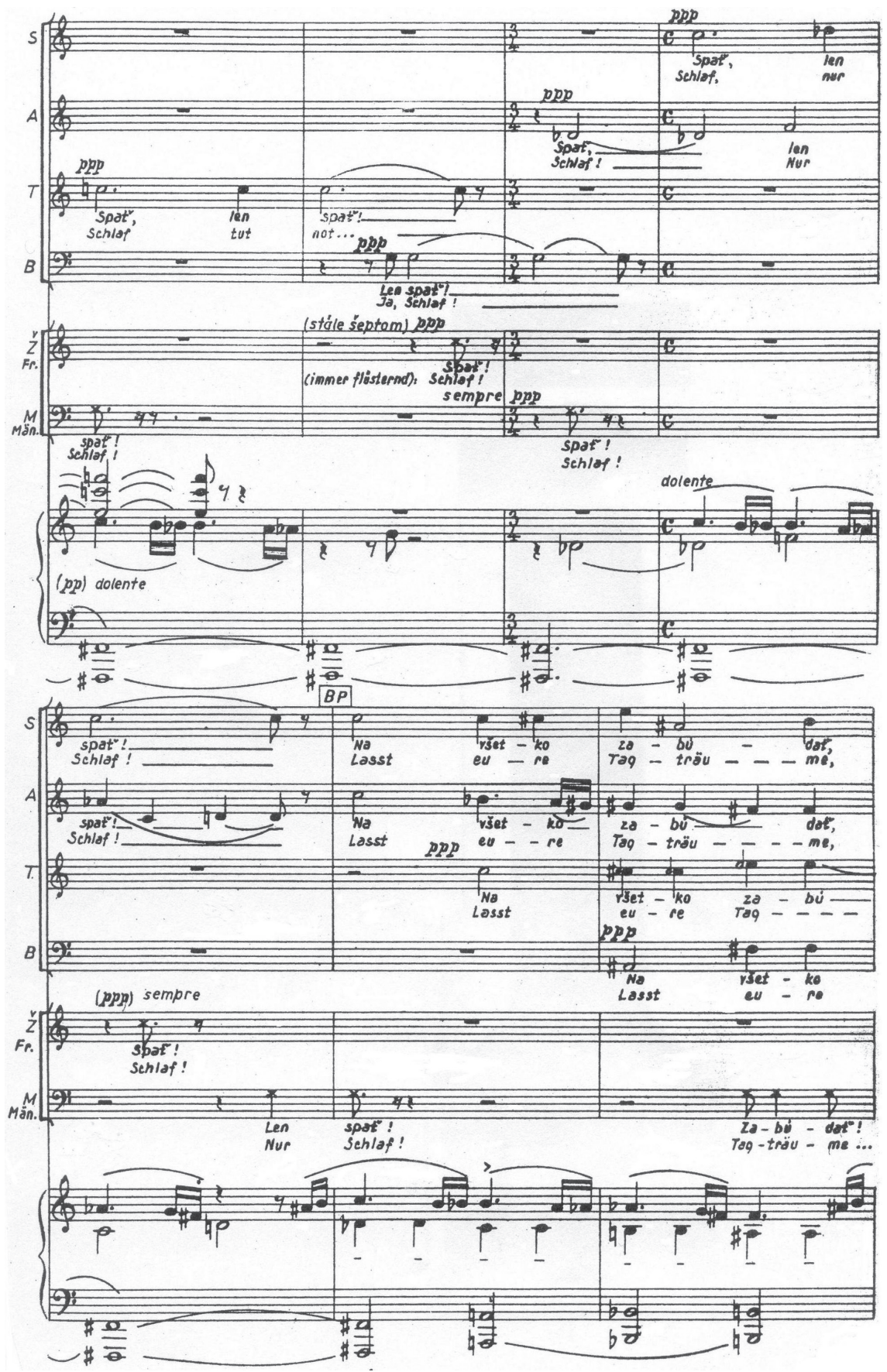


(The audience of the premiere [of Hra o láske a smrti] in Munich seemed nevertheless to love the piece: an overwhelming applause for the soloists ..., bravos for the present composer. And I have not heard so many people using their handkerchiefs for a long time. Apparently, sentimentality sells well, and the quality requirements are adapted accordingly.)

And some of them blame the opera houses, "the decrepit institution of opera" (keuchende Institution Oper), ${ }^{48}$ of incompetence and lack of discrimination because they put such pieces into the repertoire. ${ }^{49}$

Cikker was convinced that his operatic humanism is beyond politics, even if he was setting highly political models like Hra o láske a smrti or Coriolanus. Some West German critics assumed both these operas, composed in the late 1960s, to be social and moral parables in the spirit of Prague Spring:

... künstlerischer Exponent des Prager Frühlings, durch ihn fand er sein Thema, die Revolution; mit ihm verstummte er ... . Der Erfolg war situationsbedingt beachtlich, aber nicht dauerhaft; man ahnt die Gründe. Cikker brach keine Regeln, er ließ lediglich davon singend erzählen. ${ }^{50}$

(... an artistic exponent of the Prague Spring, through it he found his subject - the revolution, and through it he fell silent ... The success was situationally remarkable, but not lasting. The reasons were obvious. Cikker broke no rules, he just let his figures sing of it.)

This was, however, self-deception. There is a grain of truth in Heinz Josef Herbort's remark that in Hra o láske a smrti Cikker has had to choose between politics and tears, and he has opted for tears. ${ }^{51}$ The composer of Mister Scrooge and Vzkriesenie was indeed involved in the de-Stalinization and the "Early Spring" in Czechoslovak culture in the late 1950s and the early 1960s. And his operas after Vzkriesenie were not influenced by the official communist ideology and aesthetics. But at the same time, the more and more explicit and more and more harmless humanism of his operas was easily made a part of the cultural canon of the "normalized" communist Czechoslovakia of the 1970s and 1980s. Lothar Sträter's comment after the world premiere of Coriolanus at the Prague National Theater is precise:

48. Koch, "Das letzte Wort eines abgeschlossenen Kapitels?"

49. See Hans-Klaus Jungheinrich, "Noch eine Oper zuviel."

50. Jürgen Schläder-Robert Braunmüller, Tradition und Zukunft. 100 Jahre Prinzregententheater München (Feldkirchen bei München: Ricordi, 1996), 110-111. See also Urs von Bernau, "Mit Blick auf Prag. In Mannheim: Cikker-Oper nach Shakespeares 'Coriolan'," Rheinischer Merkur [Köln] (13 December 1974).

51. Herbort, "Herrgott, wann wird das ein Ende nehmen?" 
Bevor man Fehlinterpretationen und Missdeutungen riskiert, macht man's lieber einfach und klar. Die kleine slowakische Nation braucht ihre Nationalkünstler. Partei und Staat waren mit höchsten Funktionären bei der Premiere. Keine Missverständnisse. Viel Beifall. ${ }^{52}$

(Before we risk misinterpretations, let's make it simple and clear. The small Slovak nation needs its national artists. The Party and the government, represented by the highest officials, were present at the premiere. No misunderstandings. Lots of applause.)

But why did the international success of Vzkriesenie and its reputation fade away in the 1970s? This opera does not lack quality, innovative aspects and consistency of the concept. There are apparently more reasons for it: the change of taste (of the critics and opera producers, and, to some extent, of the audience) and change of attitude towards the more or less realistic narrations of "the old Literaturoper"; the decrease of the fascination with great stories and great storytellers from the East, like Tolstoy and Dostoyevsky, and, temporarily, Cikker; and, last but not least, the owner of Bärenreiter, Karl Vötterle, died in 1975, and his heirs naturally followed their own affinities in Bärenreiter's publishing policy and promoted other contemporary composers.

I met Ján Cikker only once. As school children in the 1980s, we were sent to a discussion with him at the Slovak Music Fund. The old master told us about Katyusha's life and suffering. Knowing neither his opera nor Tolstoy's novel, I had a feeling he was speaking about somebody he knew personally. There were tears in his eyes. Later, after Cikker's death, Mrs. Cikker told me that while working on Vzkriesenie, Cikker would sometimes play excerpts from it for his friend, the poet Ján Smrek, and when she entered the room during those sessions, she sometimes would have seen tears in their eyes. Some West German reviews from the $1960 \mathrm{~s}$ also report about tears of compassion in the spectators' eyes, even about the use of handkerchiefs in the opera houses during performances of Cikker's operas. All those tears were authentic and legitimate. Nevertheless they have dried. Probably there still exist opera lovers who own handkerchiefs. But I suppose they will today prefer to go to see La traviata or La bohème than Cikker's Vzkriesenie. 